\title{
On the finding of Polyommatus icadius (Groum-Grshimanlo, 1890) (Lepidoptera: Lycaenidae) in the plains of the south-east of European Russia
}

\section{О нахождении Polyommatus icadius (Groum-Grshimanlo, 1890) (Lepidoptera: Lycaenidae) в равнинной части юго-востока европейской России}

\author{
S.K. Korb ${ }^{1}$, B.V. Stradomsky ${ }^{2}$ \\ С.К. Корб ${ }^{1}$, Б.В. Страдомский ${ }^{2}$
}

\footnotetext{
${ }^{1}$ Russian Entomological Society, Nizhny Novgorod Branch, Russian Academy of Sciences, P.O.Box 97, Nizhny Novgorod, 603009 Russia. E-mail: stanislavkorb@list.ru

${ }^{1}$ Русское энтомологическое общество, Нижегородское отделение, а/я 97, Нижний Новгород 603009, Россия.

${ }^{2}$ Institute of Arid Zones SSC RAS, Chekhov str., 41, Rostov-on-Don 344006 Russia. E-mail: bvstr@yandex.ru

2 Институт аридных зон ЮНЦ РАН, пр. Чехова, 41, Ростов-на-Дону 344006, Россия.
}

KEY WORDS: Polyommatus icadius, south-east Russia, new finding.

КЛЮЧЕВЫЕ СЛОВА: Polyommatus icadius, юго-восточная Европа, новое местонахождение.

ABSTRACT. From vicinity of Dosang in the Astrakhan Province (Russia) we record a mountainous blue butterfly species Polyommatus icadius. Molecular genetic markers (COI and ITS2) are studied.

РЕЗЮМЕ. Из окрестностей пос. Досанг в Астраханской области России указывается горный вид голубянок Polyommatus icadius. Изучены молекулярно-генетические маркеры (COI and ITS2).

Polyommatus icadius (Groum-Grshimaïlo, 1890) is a widespread species in the mountains of Central and Eastern Palearctic (Central Asia, Dzungaria mountains of South East Kazakhstan and North-West China, Northern Mongolia, Altai, Tuva, Iran, Afghanistan, NorthWestern Caucasus), has not yet been discovered at the altitudes under $1000 \mathrm{~m}$ above sea level.

In 2010 , S.K. Korb collected in the Astrakhan region of Russia a small series of $P$. icadius: $3 \sigma^{7} \sigma^{7}$, Russia, Astrakhan area, Dosang vill., 2.05.2010, S. Korb (Figs 1-2). Butterflies were collected in the same habitat (Fig. 3), where in 1999 was found other Central Asian blue butterflies species - Praephilotes anthracias (Christoph, 1877) [Eitschberger, Zolotuhin, 1999]. However, the complete confidence that this is P. icadius, was not present: P. icarus (Rottemburg, 1775) was known from this region [Lvovsky, 1971; Morgun, 2003]. To determine the species of collected specimens we analyzed two nucleotide sequences: mitochondrial COI (GenBank accession No. KX247290) and nuclear ITS2 (GenBank accession No. KX247292).

This analysis confirmed that our specimens belong to $P$. icadius on both sequences (Figs 4-5).

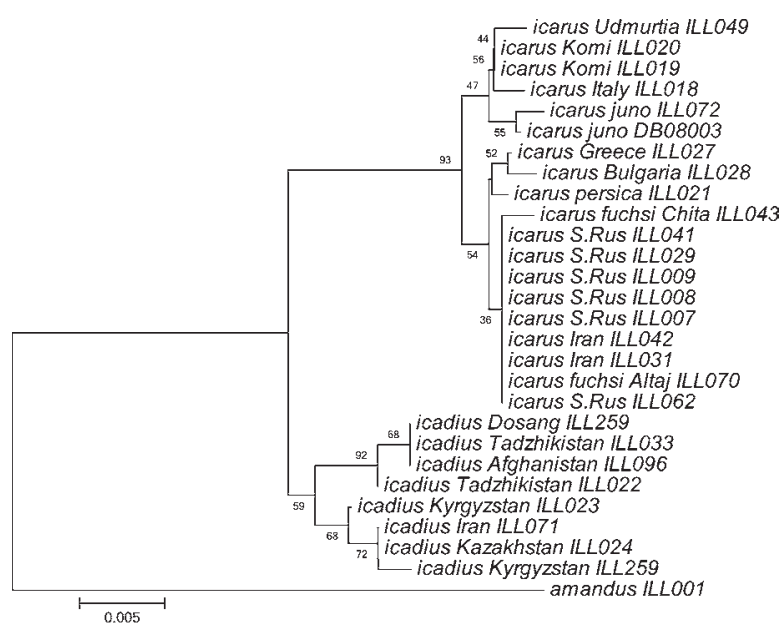

4

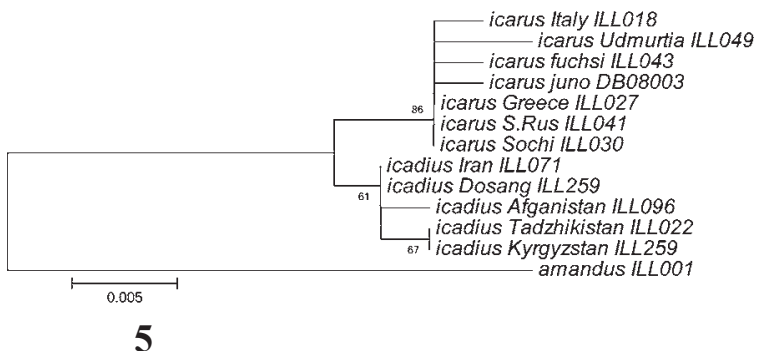

Figs 4-5. ME-cladograms of COI (4) and ITS (5) sequences within the group P. icarus - P. icadius.

Рис. 4-5. МЕ-дерева последовательностей COI (4) и ITS (5) в группе $P$. icarus $-P$. icadius. 

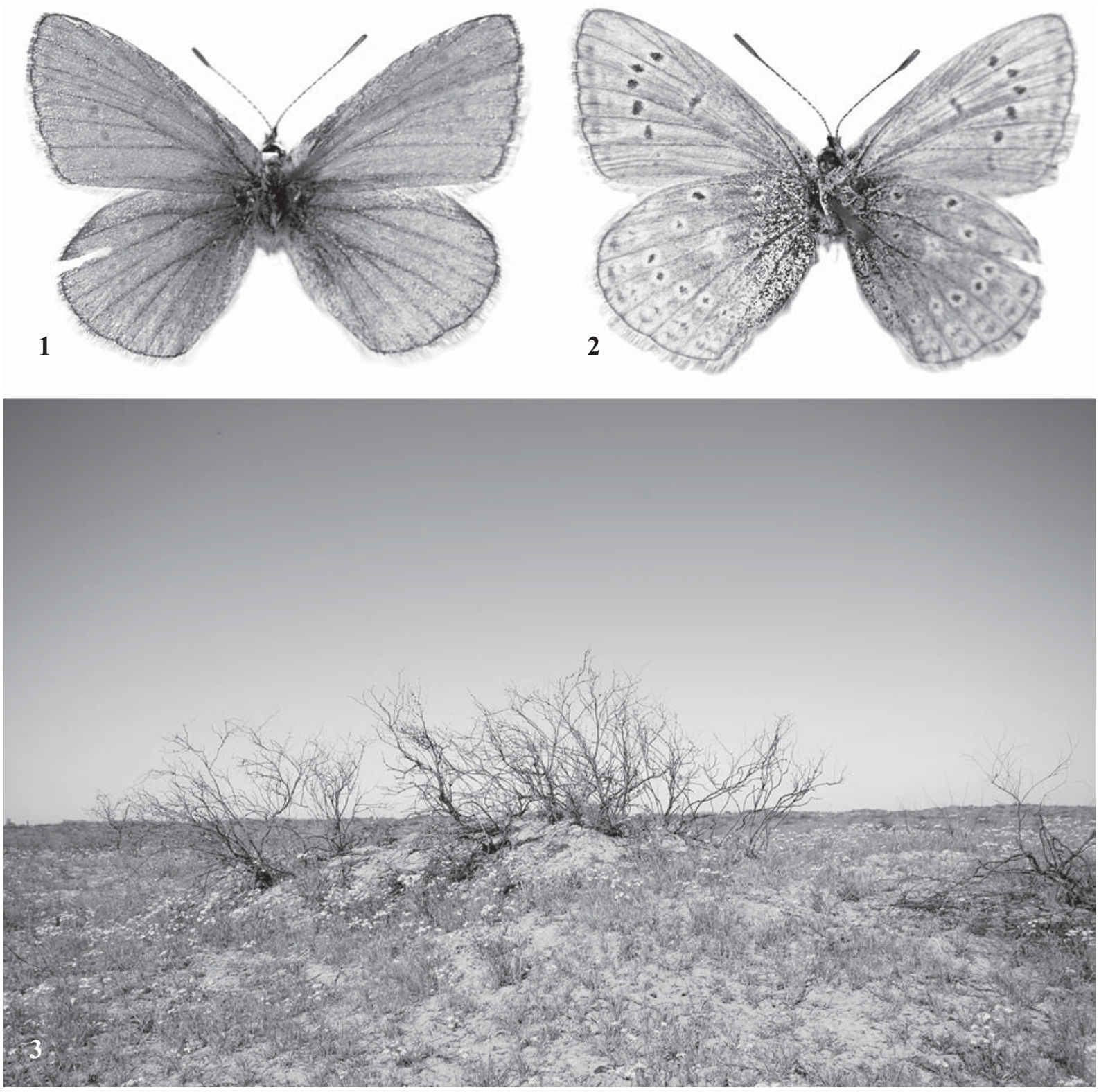

Figs 1-3. Polyommatus icadius (Groum-Grshimaïlo, 1890): 1 - dorsal view; 2 - ventral view; 3 - habitat. Pис. 1-3. Polyommatus icadius (Groum-Grshimaïlo, 1890): 1 - сверху; 2 - снизу; 3 - местообитание.

\section{References}

Eitschberger U., Zolotuhin V.V. 1999. Praephilotes anthracias (Christoph, 1877) - eine neue Tagfalter-Gattung und -Art für Europa (Lepidoptera, Lycaenidae) // Atalanta. Bd.29. S 141-148.
Lvovsky A.L. 1971. [Materials on the fauna of Macrolepidoptera of the Astrakhan region] // Entomologicheskoe obozrenie. Vol.50. No.4. P.800-810 [in Russian].

Morgun D.V. 2003. Butterflies (Lepidoptera: Rhopalocera) of the Astrakhan Province // Russian entomological Journal. Vol.12. No.2. P.227-238 